\title{
$\mathrm{SBR}$ 을 이용한 선박오수 고도처리장치 개발
}

\author{
김인수*·오염재**•+ 이언승 \\ *한국해양대학교 토목환경공학부 교수, **, 한국해양대학교 대학원
}

\section{Shipboard sewage treatment using Sequence Batch Reactor}

\author{
In-Soo Kim* • Yeom-Jae Oh** • † Eon-Sung Lee \\ *Division of Civil and Environment, National Korea Maritime University, Pusan 606-791, Korea \\ **, + Graduate school of National Korea Maritime University, Pusan 606-791, Korea
}

\begin{abstract}
요 약 : 본 연구에서는 선박오수 고도처리시스템 개발을 목적으로 SBR 공법을 도입하여 선박용 오수처리장치를 제작한 후 성능 평가를 수 행하였다. Lab scale 과 Pilot Plant 규모의 기초 실험을 토대로 제작한 시제품은 시운전 결과 IMO의 Res.MEPC.159(55) 성능 기준을 충분히 만족시켰으며, 질소와 인의 동시처리도 가능하여 강화되어 가는 해양환경기준을 충분히 만족시킬 수 있을 것으로 평가되었다. 선박오수와 유사 한 실 하폐수를 대상으로 한 제품 가동 결과 유기물의 경우 $90 \%$ 이상, 질소와 인의 경우 $50 \%$ 이상의 처리 효율을 나타내었으며, 운전 기간 내 내 안정적인 처리 효율을 보이며 선박이라는 특수한 환경과의 접목성도 매우 우수한 시스템으로 확인되었다.
\end{abstract}

핵심용어 : 국제해사기구, 선박 오수, 바실러스균, 연속회분식 반응조

Abstract : This study was carried out for advanced treatment development on shipboard sewage. We employed SBR process using Bacillus sp. to remove Organic compounds, Nitrogen and Phosphorus simultaneously. Based on Res. MEPC.159(55) the system was qualified. From the results it was suggested that SBR system might be suitable process for shipboard sewage treatment in terms of pollutant removal efficiency, maintenance and special environmental conditions of ship. More than $90 \%$ of $C O D$ and BOD were removed. In addition, aover $50 \%$ of $T-N$ and $T-P$ were reduced.

Key words : IMO, shipboard sweage, Bacillus sp., sequence beach reactor

\section{1. 서 론}

국제해사기구(IMO, International Maritime Organization) MARPOL 73/78의 부속서 $\mathrm{IV}$ 의 조항 중 선박에서 오수를 배출 할 경우 200톤 이상의 선박은 육상 정화조 설비와 유사한 오수 처리장치에서 처리한 후 배출해야 하는 국제 협약이 발효되었 다(박 등, 2005). 현재 $\mathrm{IMO}$ 에서는 $\mathrm{pH}, \mathrm{BOD}, \mathrm{COD}, \mathrm{SS}$, 열저항 성 대장균, 잔류염소만을 규제하고, 질소와 인에 대한 규제는 제정되어 있지 않아, 국내에서 시판되고 있는 선박오수처리시 스템은 일반 유기물만 제거할 수 있어 부영양화와 적조의 주 범이 되는 질소와 인의 처리는 미흡한 실정이다. 하지만 육상 처리시설에서는 질소, 인을 처리할 수 있는 고도처리 공법을 이미 도입하여 처리하고 있어 유기물과 함께 질소와 인을 동 시에 효과적으로 제거할 수 있는 선박용 오수처리시스템의 개 발은 장기적인 관점에서 필수적 과제라 할 수 있겠다.

선박용 오수처리시스템은 선박이라는 특수한 환경에서 발생 하는 분뇨 및 오폐수를 선박 자체에서 처리하여 배출할 수 있 는 시스템으로 각종 시설이 밀집된 협소한 공간 내에 설치해 야 한다는 공간적 특수성과 오수량과 배출 농도가 불균일하여
부하 변동이 심하다는 시료의 특수성에 안정적이며 유동적으 로 대처 가능하고 선박 내 배관시스템과의 접목성과 자동 제 어 등의 시스템적인 부분을 만족할 수 있으면서 처리능력이 양호하여야 한다.

$\mathrm{SBR}$ (Sequence Batch Reactor, 연속회분식반응조) 시스템은 공간적인 개념을 시간 개념으로 전환하여 구조를 콤팩트화한 장치로 요구되는 소요면적이 작아 선박이라는 특수 환경을 고 려할 때 공간 활용 면에서 매우 유리한 공정이다. 또한 $\mathrm{SBR}$ 시스템 운영을 위해 우점화한 바실러스 균주(Bacillus sp.)는 오폐수의 부하변동이나 온도변화에 대한 적응력이 우수하여 유지관리가 용이할 뿐만 아니라 안정된 처리 효율을 보이며 발생슬러지 또한 최소화 할 수 있어 선박오수처리장치로의 적 용에 매우 적합 할 것으로 판단된다.

이에 본 연구에서는 선박용 고도처리시스템 개발을 목적으 로 바실러스 균주(Bacillus sp.)를 이용한 SBR 공법을 도입하 여 Lab scale과 Pilot Plant 규모의 기초 실험을 수행하였고, 이를 토대로 시제품을 제작한 후 IMO의 Res. MEPC.159(55) 에 의거하여 그 성능을 확인하였다.

\footnotetext{
† 교신저자 : 정회원, les@ks.ac.kr 051)410-4983

* 종신회원, iskim@hhu.ac.kr, 051)410-4416

** 정회원, herolight@nate.com 051)410-4983
} 


\section{2. 실험장치 및 실험방법}

\section{1 실험장치}

1) Lab scale SBR system

Pilot Plant 제작을 위해 실험실 규모의 SBR system을 만들 어 기초 실험을 수행하였으며 개략도는 Fig. 1과 같다. 내부의 미생물 상태를 확인하기 위하여 두께 $5 \mathrm{~mm}$ 의 투명 아크릴로 전 체 용적 $14 \ell$ 의 원형조를 만들고 정량펌프 및 교반기, 반응조 아래에 산기관을 설치하였다. 운전시간조절장치와 PLC(Power Line Communication) 회로를 이용하여 운전시간을 조절하였 고, 정량펌프를 이용하여 미량조절이 가능하게 하였으며, 항온 항습기를 사용하여 반응조의 온도는 $20^{\circ} \mathrm{C}$ 로 일정하게 유지할 수 있도록 하였다.

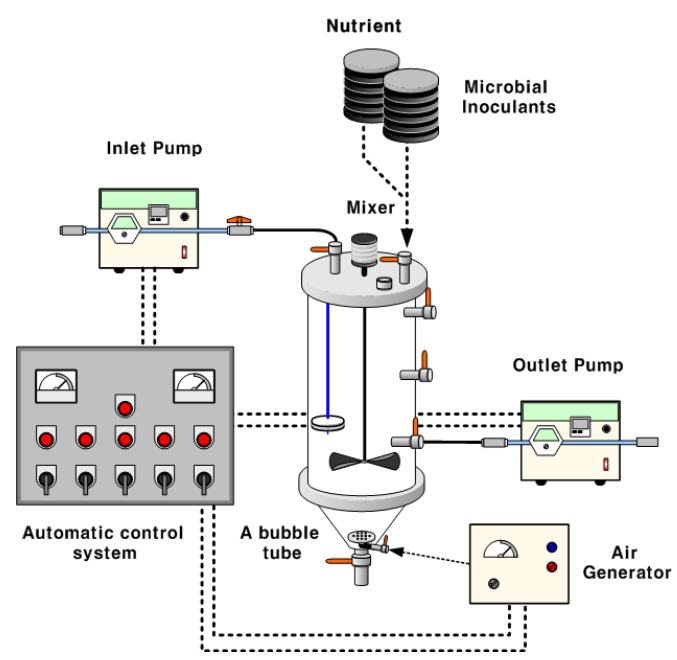

Fig. 1 Schematic diagram of SBR system

\section{2) Pilot Plant}

기초 실험결과를 바탕으로 Pilot Plant를 $2.8 \mathrm{~m}^{3} / \mathrm{d}$ 의 용량으로 설계 - 제작하였으며 실물 사진은 Fig. 2와 같다. Pilot Plant는

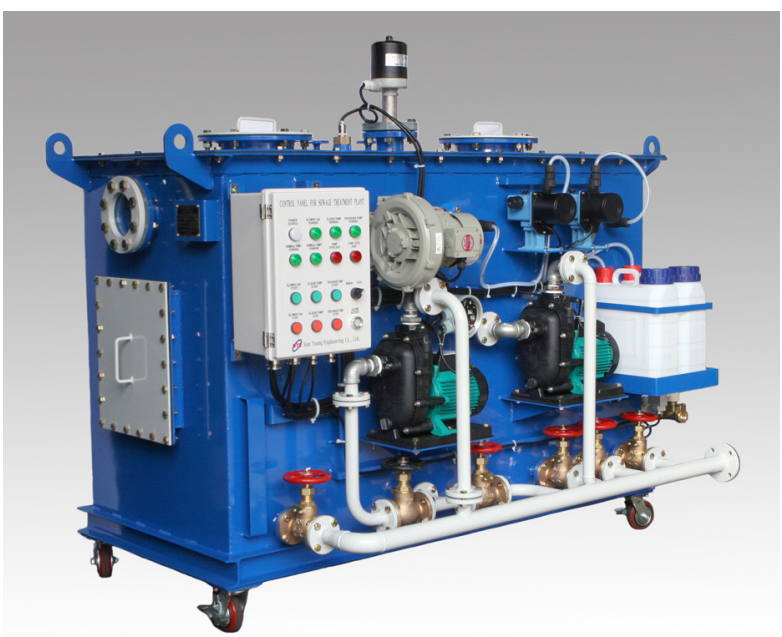

Fig. 2 Picture of pilot plant
$\mathrm{SBR}$ 공정을 포함하여 여과와 살균처리시설 등으로 구성되어 있으며 본 연구에서는 $\mathrm{SBR}$ 공정에 의한 오염특성을 확인하기 위하여 생물학적 반응이 끝나고 반응조에서 여과조로 유입되 는 유입수를 채취하여 실험을 수행하였다.

\section{3) 시제품}

Pilot Plant 가동 실험을 통해 얻은 실험결과를 바탕으로 시 제품을 설계·제작하여 최종 실험을 수행하였으며, 제작한 시 제품의 실물 사진과 SBR 반응조 부분의 설계 치수를 Fig. 3에 나타내었다.
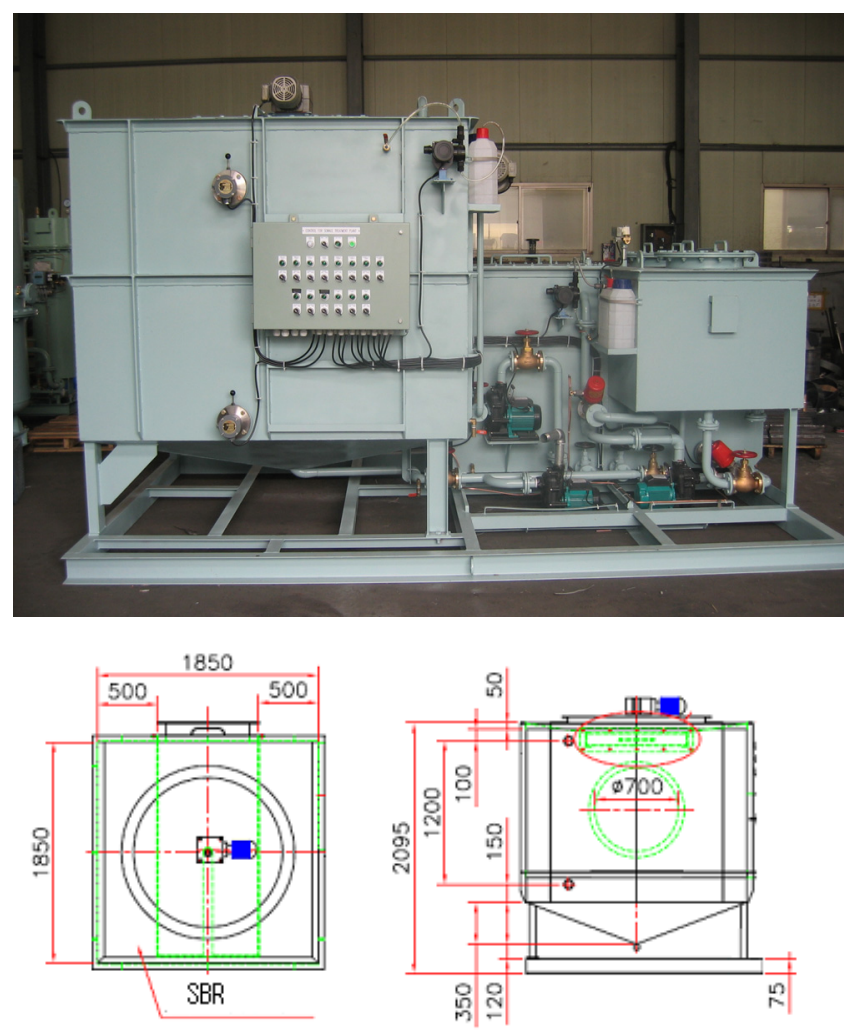

Fig. 3 Picture of product

시제품은 형식 승인을 전제로 하므로 기업체의 상황에 맞게 120 인승용 $\left(12 \mathrm{~m}^{3} / \mathrm{d}\right.$ 처리용량)으로 제작하였으며, 반응조를 비롯 한 여과조, 역세수 탱크, 살균조 등으로 구성되어 있다. Pilot Plant와 마친가지로 SBR 시스템에 의한 처리효율만을 비교하 기 위하여 생물학적 반응이 끝나고 반응조에서 여과조로 유입 되는 유입수를 채취하여 실험을 수행하였으며, 열저항성 대장 균, 잔류염소의 경우 살균조에서 처리된 유출수를 시료로 하여 분석하였다. 살균조는 염소와 처리수의 원활한 교반을 위하여 감속기를 설치하였으며 염소는 정량펌프를 사용하여 주입하 였다.

\section{2 실험방법}

1) 미생물 접종 및 관찰

본 연구에 사용된 식종슬러지는 울산의 $\mathrm{S}$ 하수처리장의 B3 
반응조(Best-Bio-Bacillus System)로부터 채취하였으며, 15일 간의 적응시간을 거친 후 반응조에 접종하였다. 기초 실험에서 반응조 내 미생물 생장 환경 및 미생물 성장 상태를 지속적으 로 확인하여 장치 운영을 위한 최적의 운전 조건을 도출하였다.

반응조 내의 공기 공급량을 조절하여 바실러스균을 우점화 시키고 그람염색을 통하여 이를 확인하였다. 위상차 현미경 (OLYMPUS BX40)으로 반응조 내의 미생물을 관찰하고 직접 계수법으로 미생물 밀도를 측정하여 바실러스균의 성장 상태 를 확인하고 영양분을 공급하여 개체수를 유지할 수 있도록 조정하였다.

또한 반응조 내부에서 1반응 주기(cycle time) 동안의 DO를 계속 측정하여 바실러스속세균의 성장특성에 맞추어 포기 강 도를 조정하였고, $\mathrm{ORP}$ 변화를 측정하여 생화학 반응의 징후를 파악하였다.

\section{2) 시료의 성상 및 분석}

선박에서 발생 되는 오·폐수의 특성(김 등, 1988)은 Table 1 과 같다.

Table 1 General characteristics of shipboard sewage

\begin{tabular}{|c|c|c|}
\hline Composition & Concentration $(\mathrm{mg} / \ell)$ & Mean $(\mathrm{mg} / \ell)$ \\
\hline $\mathrm{COD}_{\mathrm{Cr}}$ & $400 \sim 500$ & 450 \\
\hline $\mathrm{T}-\mathrm{N}$ & $25 \sim 30$ & 27.5 \\
\hline $\mathrm{T}-\mathrm{P}$ & $4 \sim 5$ & 4.5 \\
\hline MBAS & $10 \sim 20$ & 15 \\
\hline Mineral oil(Diesel) & $1.3 \sim 1.7$ & 1.5 \\
\hline Animal Fat & $1.4 \sim 1.6$ & 1.5 \\
\hline Vegetable oil & $1.4 \sim 1.6$ & 1.5 \\
\hline
\end{tabular}

Lab scale SBR 반응조를 이용한 기초 실험 및 Pilot Plant 가동에 사용한 시료는 실험의 편의를 위하여 글루코스를 탄소 원으로 하여 유기물 농도를 조정하고, $\mathrm{NH}_{4} \mathrm{Cl}$ 및 $\mathrm{K}_{2} \mathrm{HPO}_{4}$ 를 사 용하여 질소와 인의 농도를 조정한 후, 미량 성분들의 조성을 맞추어 Table 1 과 같은 농도로 인공폐수를 조제하여 시험하였 다. 시제품의 설계인자 도출을 위하여 Lab scale 및 Pilot Plant 에서는 유기물 및 질소와 인의 제거 효율을 측정하였다.

시제품은 한국해양대학교 학생기숙사에서 발생되는 오폐수 를 이용하여 선박에서 배출되는 오폐수와 거의 유사한 실제 시료로 가동하여 현장 실험과 가까운 데이터를 얻을 수 있도 록 하였다. 기숙사 아래 오폐수 맨홀에서 유입시킨 오폐수는 $\mathrm{BOD} 210 \mathrm{mg} / \ell, \mathrm{COD} 150 \mathrm{mg} / \ell$ 등으로 $\mathrm{IMO}$ 가 정한 성능 시험 시료로 적합함을 확인하였으며 그 특성은 Table 2에 나타내 었다.

시제품의 성능평가는 국제해사기구(IMO) 해양환경보호위원 회(MEPC)에서 새롭게 개정한 Res.MEPC.159(55)를 기준으로 수행하였으며, 그 기준은 Table 3 과 같다. 규제치가 명시되어 있는 $\mathrm{BOD}, \mathrm{COD}, \mathrm{pH}, \mathrm{SS}$, Thermotolerant Coliform, Chlorine
을 측정하여 $\mathrm{IMO}$ 가 정한 성능평가를 수행하였으며, 질소 및 인은 아직 규제치가 제정되어 있지 않으므로 수질환경법의 방 류수 수질기준을 기준으로 하여 기준치 만족여부와 질소, 인의 고도처리 효율을 확인하였다.

Table 2 Characteristics of influent in product

\begin{tabular}{|c|c|}
\hline Composition & Concentration $(\mathrm{mg} / \ell)$ \\
\hline COD & $100 \sim 200$ \\
\hline BOD & $200 \sim 300$ \\
\hline T-N & $20 \sim 125$ \\
\hline T-P & $5 \sim 15$ \\
\hline SS & $150 \sim 350$ \\
\hline
\end{tabular}

Table 3 Contents of Res.MEPC.159(55)

\begin{tabular}{|c|c|}
\hline Content & regulation \\
\hline $\mathrm{BOD}_{5}$ & below $25 \mathrm{mg} / \ell$ \\
\hline $\mathrm{COD}$ & below $125 \mathrm{mg} / \ell$ \\
\hline $\mathrm{pH}$ & $6 \sim 8.5$ below \\
\hline $\mathrm{SS}$ & below $35 \mathrm{mg} / \ell$ \\
\hline Thermotolerant Coliform & 100 cell $/ 100 \mathrm{~m} \ell$ \\
\hline chlorine (for disinfectant) & below $0.5 \mathrm{mg} / \ell$ \\
\hline
\end{tabular}

Res.MEPC.159(55)에서는 오폐수처리장치의 성능 평가를 위 해 10 일 동안 1 일 4 회 시료를 채취하여 총 40 개의 샘플을 분석 할 것을 명시하고 있다. 이 기준을 충족시키기 위하여 본 연구 에서는 Pilot Plant와 시제품을 20일 동안 가동하였으며, 모든 실험은 실험 분석치가 안정화되는 정상상태에서 유입수와 처 리수에 대하여 1 주기인 360 분에 한번씩 1 일 4회 시료를 취하 여 성능 검사를 수행하였다.

측정항목 및 인공폐수 성분의 항목별 분석 방법은 수질오염 공정시험법(2003) 및 Standard Methods을 참조하였으며 각 항 목별 분석방법은 Table 4에 나타내었다.

Table 4 Analytical method

\begin{tabular}{|c|c|}
\hline Test item & Test Method \\
\hline $\mathrm{pH}$ & $\mathrm{pH}$ metar(Thermo Orion 720) \\
\hline DO & DO Metar (YSI Model 58) \\
\hline ORP & ORP metar(Thermo Orion 720) \\
\hline BOD & ISO 5815-1 \\
\hline COD & MPN 15705 \\
\hline $\begin{array}{c}\text { Thermotolerant } \\
\text { Coliform }\end{array}$ & Standard Method 2540D \\
\hline SS & Standard Method 4500 Cl B \\
\hline Chlorine & UV Spectrophotometric Mehtod \\
\hline TN & $\begin{array}{c}\text { Automated Ascorbic Acid Reduction } \\
\text { Method }\end{array}$ \\
\hline TP
\end{tabular}




\section{3. 실험결과 및 고찰}

\subsection{SBR system 내 미생물 관찰}

반응조의 미생물 관찰을 통해 바실러스균의 성장은 양호하 고 우점화되어 있는 것으로 나타났다. 그람염색을 통해 그람양 성 세균인 바실러스균은 자색으로 그람음성 세균은 적색으로 염색되어 반응조 내의 미생물을 구분할 수 있었다.
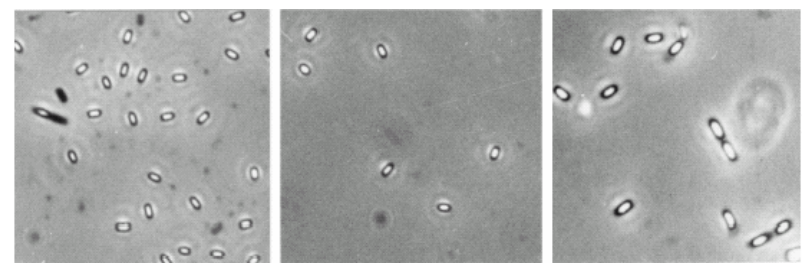

(a) spores in settle
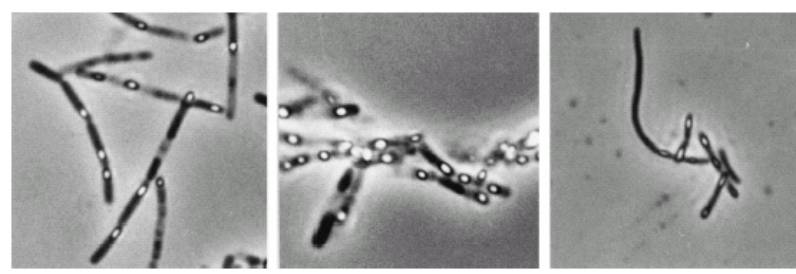

(b) endospores in anoxic

Fig. 4 Picture of bacillus sp. $(\times 300)$

위상차 현미경을 통하여 관찰한 바실러스균은 유기물이 풍 부할 때는 플럭에 부착된 사상체 형태로 관찰이 되며 무산소 상태와 영양분이 부족할 때에는 필라멘트 형태가 끊어지면서 단간균 형태를 형성하거나 또는 포자로 발아하였다. Fig. 4에 반응조 내 바실러스균의 변화를 나타내었다. Fig. 4의 (a)는 영 양분이 결핍되어 생육이 저해되는 침전주기로 바실러스균은 포자로 발아하며 포자는 광학적 굴절률이 아주 뛰어나므로 현 미경 상에서 다른 미생물들과 쉽게 구분할 수 있었다. Fig. 4의 (b)는 호기주기에서 무산소주기로 변하는 단계에서 관찰한 사 진으로 바실러스균은 유기체 플럭에 부착된 실모양의 긴 사상 체의 형태로 관찰되었다. 위와 같이 위상차 현미경을 통해 실 시간으로 반응조의 미생물 상태를 판단할 수 있었다.

바실러스균의 우점화를 위한 점감포기 단계 도출은 Pour Plate Method로 미생물 밀도를 비교 관찰하면서 수행하였으 며, Lab scale 시스템에서의 용존산소(DO)는 산기관의 포기강 도를 조절하여 1 단계는 $1.5 \sim 2 \mathrm{mg} / \ell, 2$ 단계 $0.8 \sim 1.0 \mathrm{mg} / \ell, 3$ 단 계 $0.5 \sim 0.8 \mathrm{mg} / \ell, 4$ 단계 $0.3 \sim 0.5 \mathrm{mg} / \ell$ 로 점감 포기 후 Anoxic 단계를 거치는 것이 바실러스 속 세균의 성장특성에 부합하는 것으로 나타나, 윤(2009)과 이(2009)의 연구 결과와 유사한 결 과를 확인할 수 있었다. 반응조 운영기간 동안 측정된 슬러지 내 생균수는 $3.2 \times 10^{6} \sim 1.2 \times 10^{7} \mathrm{CFU} / \mathrm{ml}$ 였으며 미생물활성제 를 주입시 최대 $4.8 \times 10^{8} \mathrm{CFU} / \mathrm{m} \ell$ 를 나타내었다. 이는 규소 $(\mathrm{Si})$ 와 칼슘 $(\mathrm{Ca})$, 마그네슘 $(\mathrm{Mg})$ 등의 무기물질을 포함하는 미생물 활성제 주입에 따른 바실러스속 세균의 초기 발아단계와 세포 분열의 촉진에 의한 것으로 사료된다(윤, 2009). 미생물활성제
주입량은 호기성 주기에는 초기원수 부하량의 $5 \%$, 식종 후 15 일 후에는 $1.5 \%$ 를 주입하는 것이 효과적임을 확인하였으며, 시제품 운영시는 유기물 평균 부하량의 $2 \%$ 를 주입하면서 가 동하였다.

위의 결과를 토대로 $\mathrm{SBR}$ 반응조작은 1 일 4 주기로 하여 반 응조 운전조건을 정할 수 있었다. 본 반응조의 모든 조작은 시 간조절기에 의해 자동으로 제어되도록 하였으며, 교반기의 강 도를 조절하여 $\mathrm{DO}$ 농도가 1 단계 $2 \sim 1.5 \mathrm{mg} / \ell$, 2단계 $1.0 \sim 10.5$ $\mathrm{mg} / \ell, 3$ 단계 $0.5 \sim 0.3 \mathrm{mg} / \ell$ 로 조절 가능하도록 설정하여 자동 운전하였으며 운전 조건은 Table 5에 나타내었다.

Table 5 Operating condition for SBR

\begin{tabular}{|c|c|c|c|c|c|c|c|c|c|}
\hline Ste & Fill & & & & & ettl & Idle & Drav & $\begin{array}{l}\text { Total } \\
\text { (min) }\end{array}$ \\
\hline nu & 10 & 60 & 60 & 60 & . & 80 & 10 & 10 & \\
\hline
\end{tabular}

Aerobic : $\square \quad$ Anoxic :

$\mathrm{SV}_{30}$ 의 변화량은 초기 운전 이후 극히 미비한 것으로 나타 나 반응조 내 미생물 농도는 자연적으로 조절되고 있음을 확 인할 수 있었다. Bacillus sp.는 내생포자를 형성하는 특성을 가지므로 주변의 환경조건의 변화에 잘 적응할 수 있고 성장 시 불리한 환경 조건에서는 포자를 형성하고 포자는 균체가 죽어도 살아남으며, 외부 생활환경이 좋아지면 다시 발아하여 영양형 균체를 형성한다. 이렇듯 활성슬러지 중에서 포자 균 체 $\rightarrow$ 포자와 같은 과정을 반복하여 고농도의 균체 유지가 가 능하다(이, 2009). 운전 기간 동안 관측한 $\mathrm{DO}$ 와 $\mathrm{ORP}$ 의 측정 값은 DO 2.0 $5.0 \mathrm{mg} / \ell$, ORP는 180 $220 \mathrm{mV}$ 로 Bacillus sp. 생 장에 적합한 환경이 유지되고 있음을 확인할 수 있었다.(최, 2001)

\subsection{Lab scale SBR system 및 Pilot Plant 실험장치 시 험 결과}

Lab scale SBR system에서 채취한 시료의 분석항목별 처리 효율을 Fig. 5에 나타내었다. 유입수의 COD, T-N, T-P의 평 균농도는 각각 450, 27.5 및 $4.5 \mathrm{mg} / \ell$ 이였으며, 유출수의 평균농 도는 $6.7,1.4,0.3 \mathrm{mg} / \ell$ 으로 각각 약 $98.5 \%, 95 \%, 93 \%$ 의 제거 효율을 나타내었다.

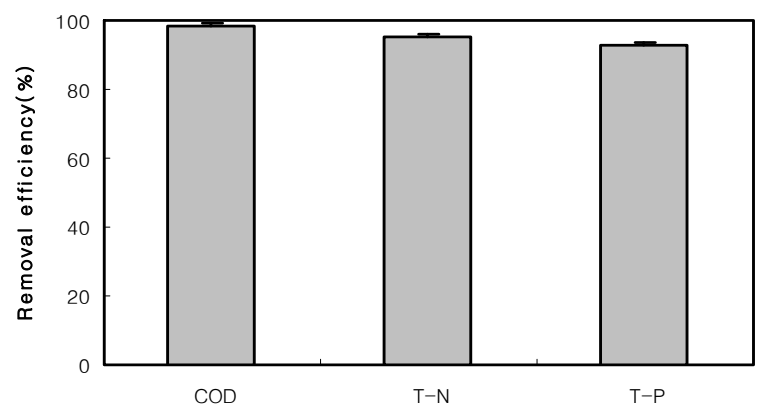

Fig. 5 Removal efficiency of COD, T-N and $\mathrm{T}-\mathrm{P}$ in the SBR system 
Pilot Plant 시험에서 유출수의 $\mathrm{COD}$ 는 평균 $40 \mathrm{mg} / \ell, \mathrm{T}-\mathrm{N}$ 과 $\mathrm{T}-\mathrm{P}$ 는 각각 평균 $12 \mathrm{mg} / \ell, 2.2 \mathrm{mg} / \ell$ 로 측정되었으며, 20 일간의 연속 가동 결과를 Fig. 6에 나타내었다. COD의 제거효율은 약 $91 \%$ 로 반응조 실험과 거의 유사한 결과를 나타내었다, T-N과 $\mathrm{T}-\mathrm{P}$ 의 경우 약 $56 \%, 51.1 \%$ 로 Lab scale에 비해서는 낮은 처 리효율을 보였으나 육상 폐수종말처리시설의 방류수 수질기준 인 $\mathrm{COD} 40 \mathrm{mg} / \ell$ 이하, $\mathrm{T}-\mathrm{N} 40 \mathrm{mg} / \ell$ 이하, $\mathrm{T}-\mathrm{P} 4 \mathrm{mg} / \ell$ 이하의 기준은 모두 만족하였다.

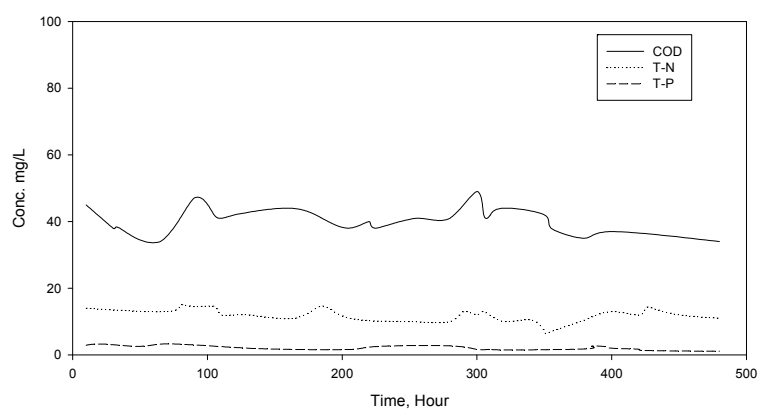

Fig. 6 Variation of $\mathrm{COD}, \mathrm{T}-\mathrm{N}$ and $\mathrm{T}-\mathrm{P}$ in Pilot Plant

\section{3 시제품 가동 결과}

선행 연구결과와 Pilot Plant 가동 시험을 통해 획득한 데이 터를 바탕으로 120 인승용 시제품을 제작하였다. 시제품은 $12 \mathrm{~m}^{3}$ $/ \mathrm{d}$ 규모로 대용량으로 설계되었음에도 불구하고 $\mathrm{SBR}$ 시스템이 차지하는 공간은 $1850 \times 1850 \times 2095 \mathrm{~mm}^{3}(\mathrm{~L} \times \mathrm{W} \times \mathrm{H})$ 으로 타 공정에 비해 선박이라는 특수 환경에서의 공간 활용이 매우 우수한 것으로 나타났다.

시제품은 한국해양대학교 내 학생기숙사에서 발생하는 오폐 수로 연속 가동하여 성능 시험을 수행하였다. 학생기숙사에서 발생하는 오폐수는 배출량과 배출되는 오폐수의 성상이 일정 하지 않아 초기 실험에 어려움이 있었으나 이 또한 실제로 선 박 오폐수 처리 시 발생할 수 있는 상황으로 시스템의 오염부 하 변동에 대한 적응성을 확인할 수 있었고 오수의 배출 농도 도 선박오수와 유사하여 현장 실험과 가까운 데이터를 얻을 수 있었다. 시제품의 연속 가동 결과 유입되는 오폐수의 성상 과 농도가 불균일 했음에도 불구하고 미생물 성장 및 처리 효 율은 매우 안정적으로 나타나 유입 부하에 대한 적응력이 매 우 우수하였으며 배출수의 농도도 $\mathrm{IMO}$ 에서 새롭게 발효한 Res.MEPC.159(55) 기준을 충분히 만족하는 것으로 나타났다.

기숙사에서 발생하는 오수 및 시제품 가동시 채취한 시료는 모두 $\mathrm{pH}$ 6 8.5를 만족시켰으며 $\mathrm{pH}$ 이외의 시제품 가동 결과 를 Fig. 7 13에 나타내었다.

Fig. 7, 8과 같이 유입수 중의 $\mathrm{BOD}$ 와 $\mathrm{COD}$ 는 평균 $210 \mathrm{mg} /$ $\ell, 150 \mathrm{mg} / \ell$, 유출수 중의 $\mathrm{BOD}$ 와 $\mathrm{COD}$ 는 평균 $17 \mathrm{mg} / \ell, 12 \mathrm{mg} /$ $\ell$ 의 농도로 나타나, 처리효율은 두 항목 모두 약 $92 \%$ 정도로 나타났다.

Fig. 9와 같이 SS의 경우, 유입수는 $150 \sim 350 \mathrm{mg} / \ell$ 로 비교적 유입수 중의 농도의 편차가 컸음에도 불구하고, 처리수는 10
$25 \mathrm{mg} / \ell$ 정도의 농도로 거의 일정하게 나타났다. 이러한 결과 는 유입수 중에 포함된 특정 성분이 유입수의 SS 농도를 높였 으며, 이 성분은 반응조에서 쉽게 처리되어 유출수의 농도에는 영향을 미치지 않은 것에 기인한 것으로 판단된다.

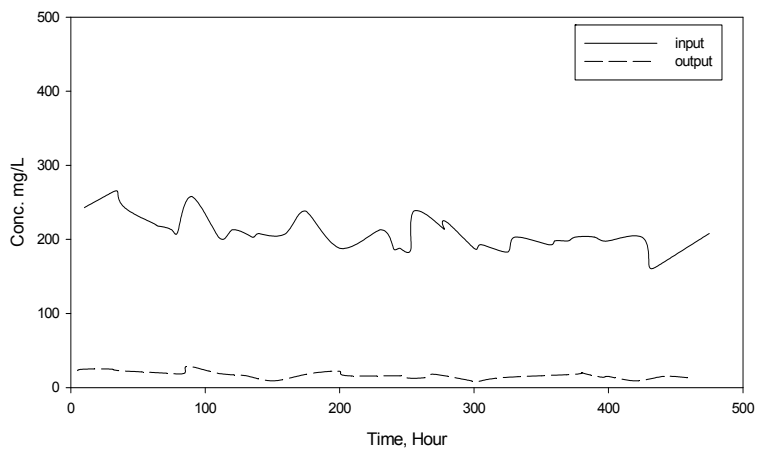

Fig. 7 Variation of BOD in product

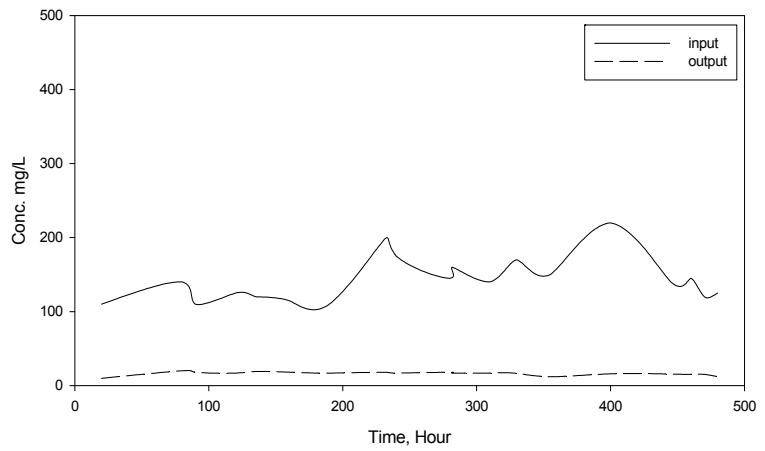

Fig. 8 Variation of COD in product

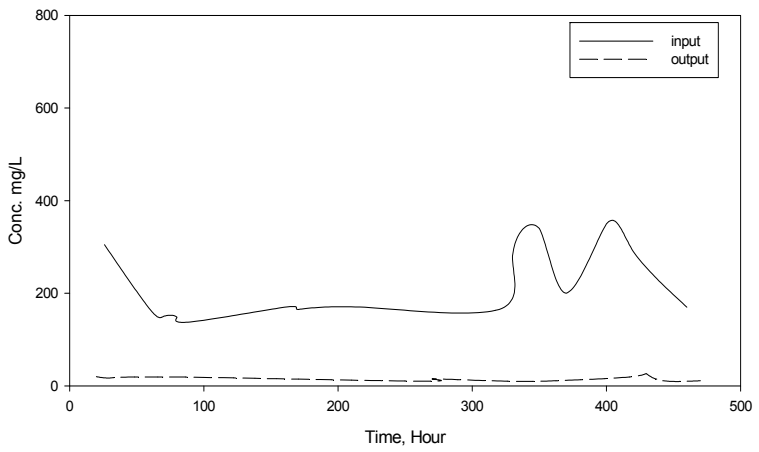

Fig. 9 Variation of SS in product

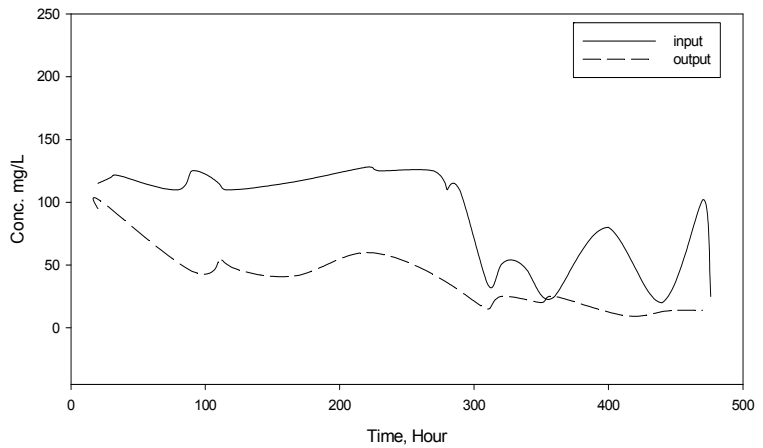

Fig. 10 Variation of $\mathrm{T}-\mathrm{N}$ in product 
Fig. 10,11 과 같이 $\mathrm{T}-\mathrm{N}$ 의 경우 유입수의 농도는 $20 \sim 125 \mathrm{mg} /$ $\ell, \mathrm{T}-\mathrm{P}$ 는 평균 $5.5 \mathrm{mg} / \ell$ 로 유입수 중에서 극히 낮은 농도를 보였으며 시제품 가동시 $\mathrm{T}-\mathrm{N}$ 과 $\mathrm{T}-\mathrm{P}$ 모두 약 $55 \%$ 정도의 처 리효율을 보였다. 생물학적 처리에서 있어 질소와 인은세포의 합성에 사용되면서 순환 제거되며, 호기와 혐기 조건에서 질산 화와 탈질 과정을 거치고, 인의 과잉 섭취와 방출 과정을 거치 면서 처리된다. 고도처리를 위해서는 인의 방출과 탈질을 위한 유기물, 즉 탄소원이 공급되어야 하나 사용 원폐수 $\mathrm{C} / \mathrm{N}$ 비 자 체가 매우 낮아 충분한 탈질이 이루어지지 않아 제거 효율이 낮게 나타난 것으로 판단된다. 이러한 결과는 다른 폐수와의 혼합 또는 외부 탄소원 추가 등으로 $\mathrm{C} / \mathrm{N}$ 비의 비율을 조정하여 운전한다면 만족할 수 있는 처리 효율을 얻을 수 있을 것으로 예상되며, 현재 $\mathrm{IMO}$ 에서 규제하고 있는 $\mathrm{COD}$ 나 $\mathrm{BOD}$ 등의 유 기물 처리에 중점을 맞추어 장치 운전을 수행하였으므로 고도 처리를 위한 운전 조건으로 변경하여 장치를 운전하면 더 높 은 제거효율을 얻을 수 있을 것으로 사료된다. 시제품의 가동 에서 비교적 낮은 처리효율을 보였음에도 불구하고 Pilot Plant 시험시와 동일하게 대부분의 유출수는 방류수 수질기준인 $\mathrm{T}-\mathrm{N} 40 \mathrm{mg} / \ell$ 이하, $\mathrm{T}-\mathrm{P} 4 \mathrm{mg} / \ell$ 이하의 기준을 만족하였다.

Fig. 12 와 Fig. 13 에 대장균군수와 잔류염소에 관한 장치 가 동 결과를 나타내었다. 장치 내의 대장균군수는 유입수의 경우 정량 범위를 벗어나 정확한 개체수를 알 수 없었으며, 처리수 중에서는 $10 \mathrm{MPN} / 100 \mathrm{~m} \ell$ 정도로 나타났다. 살균을 위해서는 액 체 형태의 차아염소산나트륨을 $10 \mathrm{ppm}$ 의 농도로 주입하면서 운전하였으며, 이에 따른 유출수의 잔류염소의 농도는 $0.3 \mathrm{mg} /$ $\ell$ 정도로 나타났다.

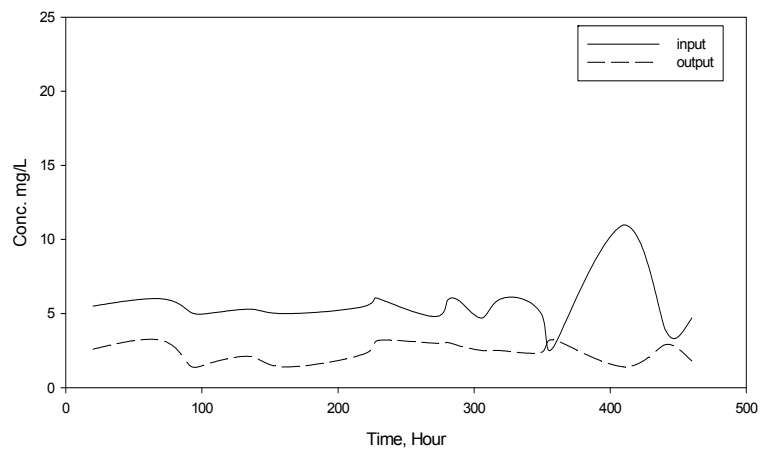

Fig. 11 Variation of $\mathrm{T}-\mathrm{P}$ in product

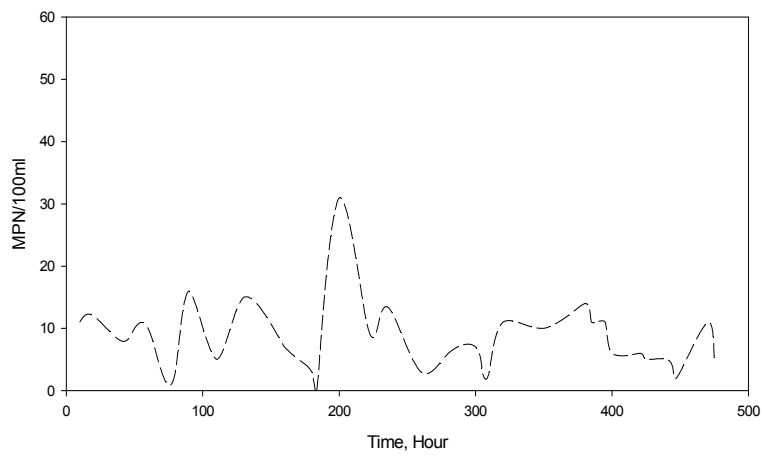

Fig. 12 Variation of coliform group in product

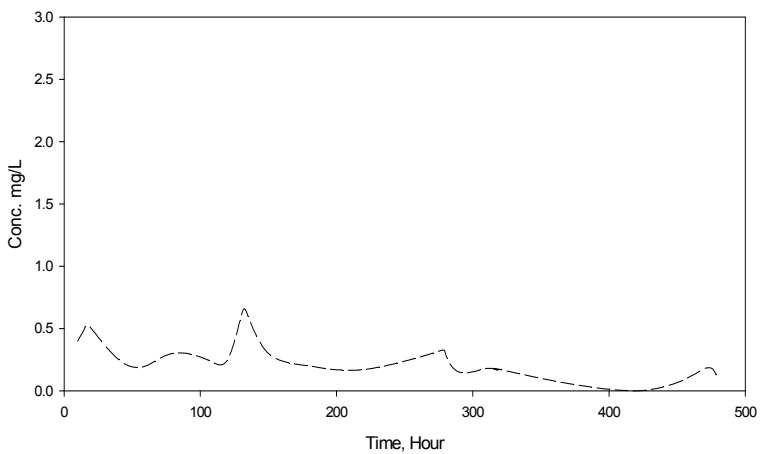

Fig. 13 Variation of chlorine in product

\section{4. 결 론}

본 연구에서는 IMO의 MARPOL 73/78 ANNEX IV의 발효 에 따른 선박용 오수처리장치 개발을 목적으로 SBR system을 이용한 기초 실험을 수행하고 Pilot Plant 운영을 거쳐 시제품 을 제작하였다. 제작한 시제품은 선박폐수와 비슷한 성상을 가 지는 실제 폐수로 가동하여 Res.MEPC.159(55) 기준 만족 여부 를 확인하고 앞으로 강화될 기준에 대비하여 수질환경법의 방 류수 수질기준으로 성능 검사를 하여 오폐수의 고도처리 능력 을 평가하였다. 실험결과를 바탕으로 한 결론은 다음과 같다.

1. 실험실 규모의 기초 실험을 통해 오염부하에 대한 미생물 의 적응력과 오염 물질의 제거 효율에 대한 기초 data를 도출 하였다. COD, T-N, T-P는 각각 약 $98.5 \%, 95 \%, 93 \%$ 의 높은 제거효율을 나타내었고, 처리효율의 변동 또한 매우 작아 오염 물질 부하에 따른 미생물의 적응력이 매우 높은 공정으로 나 타났다.

2. 15 인승 선박용 오폐수처리장치 규모의 Pilot Plant를 제작 하여 운영한 결과 $\mathrm{COD}$ 의 제거효율은 약 $91 \%, \mathrm{~T}-\mathrm{N}$ 과 $\mathrm{T}-\mathrm{P}$ 의 경우 약 $56 \%, 51.1 \%$ 로 기초 실험에 비해서는 낮은 효율을 나 타내었지만 유출수의 농도는 기준을 모두 만족하여 시스템의 현장 적용을 긍정적으로 검토할 수 있었다.

3. 시제품(하루 $12000 \ell$ 처리용량, 120 인용) 중 SBR 시스템의 성능 평가 결과 유출수 중의 $\mathrm{BOD}$ 와 $\mathrm{COD}$ 는 평균농도 $17 \mathrm{mg} /$ $\ell, 12 \mathrm{mg} / \ell$ 로 측정되어, 처리효율은 두 항목 모두 약 $92 \%$ 로 나타났다. 처리수의 $\mathrm{SS}$ 는 $15 \sim 25 \mathrm{mg} / \ell$, 대장균군의 경우 평균 $10 \mathrm{MPN} / 100 \mathrm{~m} \ell$, 염소는 $0.3 \mathrm{mg} / \ell$ 정도의 농도를 유지하여, $\mathrm{IMO}$ 의 Res.MEPC.159(55) 기준을 충분히 만족하였다.

또한 시제품 중 $\mathrm{SBR}$ 시스템이 차지하는 면적은 약 $3.5 \mathrm{~m}^{2}$ 으로 타 공정에 비해 설치면적이 매우 작아 공간 활용이 매우 우수 한 것으로 나타났으며, 불안정한 유입수에 대해 안정적인 수처 리 능력을 나타내어 선박이라는 특수한 환경에 적용하여 실용 화할 수 있는 시스템임을 확인하였다.

4. 강화될 기준에 대비한 시제품의 고도처리 능력 평가에서 $\mathrm{T}-\mathrm{N}, \mathrm{T}-\mathrm{P}$ 의 처리효율은 $50 \%$ 정도로 낮게 나타났으나, 대부 분의 유출수의 농도는 방류수 수질기준을 만족시켜 고도 처리 용도로도 적용 가능한 공법임을 확인하였다. 선박폐수의 특성 을 고려한 유입수의 전처리 및 장치의 운전 방식을 변화시키 
면 더 높은 처리효율도 얻을 수 있을 것으로 사료되며 추후 이

에 관한 연구도 진행할 예정이다.

\section{참 고 문 헌}

[1] 김인수, 김억조, 김동근, 고성정, 안종수(1998), “선박용수의 재사용에 관한 기초연구(1)”, 해양안전학회 제 4권 제4호, pp. $41 \sim 48$

[2] 박상호, 김인수(2005), “선박에 대하여 변화되는 환경규제 와 대응책", 한국항해항만학회 제28권 제8호 pp.767 773

[3] 수질환경보존법(2009), 환경부

[4] 안태석, 홍선희, 김옥선, 유재준, 전선옥, 최승익(2001), "B3 공법을 사용하는 하수종말처리장에서 Bacillus 속 세균의 변화”, 미생물학회지 제 37권 제3호, pp.209 213

[5] 엄태규, 김영철(1999), "바실러스균을 이용한 SBR 공정의 오·폐수처리 system 연구” 경성대학교 환경문제연구소 논문집

[6] 윤상철(2009), “수정 $\mathrm{RABC}$ 공정을 이용한 질소 및 인의 제 거특성에 관한 연구” 학위논문

[7] 이진석(2009), "Bacillus sp.을 이용한 간접포기 SBR공정을 이용한 통한 축산 비료의 액비화”, 학위논문

[8] 최석조(2001), "Bacillus sp.을 이용한 연속회분식 바응조의 $\mathrm{HRT}$ 에 따른 유기물질 및 $\mathrm{N}, \mathrm{P}$ 의 제거특성”, 학위논문

[9] 최용수, 권용운(2004), "B3 공법을 이용한 하 - 폐수의 고도 처리”, 한국물환경학회 - 대한상하수도학회 - 한국수도협회 공동춘계학술발표회 논문집, pp.235 238

원고접수일 : 2010년 1월 15일 심사완료일 : 2010년 5월 10일 원고채택일 : 2010년 5월 19일 